\title{
Integrating community based disaster risk reduction and climate change adaptation: examples from the Pacific
}

\author{
A. Gero, K. Méheux, and D. Dominey-Howes \\ Australian Tsunami Research Centre and Natural Hazards Research Laboratory, University of New South Wales, \\ Sydney, NSW 2052, Australia
}

Received: 18 June 2010 - Revised: 9 November 2010 - Accepted: 10 December 2010 - Published: 10 January 2011

\begin{abstract}
It is acknowledged by academics and development practitioners alike that many common strategies addressing community based disaster risk reduction and climate change adaptation duplicate each other. Thus, there is a strong push to integrate the two fields to enhance aid effectiveness and reduce confusion for communities. Examples of community based disaster risk reduction (DRR) and climate change adaptation (CCA) projects are presented to highlight some of the ways these issues are tackled in the Pacific. Various approaches are employed but all aim to reduce the vulnerability and enhance the resilience of local communities to the impacts of climate change and disasters. By focusing on three case studies, elements of best practice are drawn out to illustrate how DRR and CCA can be integrated for enhanced aid effectiveness, and also look at ways in which these two often overlapping fields can be better coordinated in ongoing and future projects. Projects that address vulnerability holistically, and target the overall needs and capacity of the community are found to be effective in enhancing the resilience of communities. By strategically developing a multistakeholder and multi-sector approach, community projects are likely to encapsulate a range of experience and skills that will benefit the community. Furthermore, by incorporating local knowledge, communities are far more likely to be engaged and actively participate in the project. From selected case studies, commonly occurring best practice methods to integrate DRR and CCA are identified and discussed and recommendations on how to overcome the common challenges also presented.
\end{abstract}

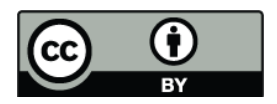

Correspondence to: A. Gero (anna.f.gero@gmail.com)

\section{Introduction}

The implications of climate change in the Pacific are expected to be severe. They include sea level rise and associated impacts (e.g. coastal erosion, storm surge, inundation and coastal hazards), changes to the nature and frequency of extreme events, and threats to water resources (Mimura et al., 2007) and food security issues (Food and Agriculture Organization, 2008). In addition to these direct impacts, climate change has the potential to compound the often devastating impacts of some of the natural hazards in the Pacific. Pacific island countries (PICs) frequently experience natural hazards such as tropical cyclones and storms, earthquakes, tsunami and volcanic activity causing significant economic and human losses. Examples include tropical cyclones Ofa and Val in Samoa in 1990 and 1991, respectively, that resulted in damage equaling four times the gross domestic product (GDP) of Samoa (Ministry of Natural Resources and Environment (MNRE), 2005); a tsunami in 2009 affecting Samoa, Tonga and American Samoa killing close to 200 people and destroying scores of coastal villages (OCHA, 2009), and flooding in Fiji in 2009 that resulted in damages of FJD\$54 million with an additional FJD\$5 million in humanitarian costs (Lal et al., 2009).

Natural hazards and climate change therefore challenge the significant investment in development in PICs. As a result, many development projects have been established that seek to address the vulnerability of Pacific Island communities to the negative impacts of climate change and natural hazards. Given the strong similarities in the methods used to reduce vulnerability to disasters and climate change, it has been argued that aid effectiveness requires the successful integration of both climate change adaptation (CCA) and disaster risk reduction (DRR) efforts (Bettencourt et al., 2006; AusAID, 2009). Although there is much discussion surrounding the topic of integration (see for example Volume 30, Issue 1 of Disasters, 2006 - a special issue focusing on integrating

Published by Copernicus Publications on behalf of the European Geosciences Union. 
DRR and CCA), to date, very little research exists on how this can be achieved in practice. This research therefore investigates specific community based projects involved in either DRR and/or CCA to highlight best practice for integration, and opportunities to advance integration in ongoing or future initiatives.

PICs are known to be intrinsically vulnerable due to their small size, insularity and remoteness, environmental factors, limited disaster mitigation capacity, demographic and economic factors (Pelling and Uitto, 2001; Kaly et al., 2002; Meheux et al., 2007). The regional climate of the Pacific, while variable, generally exhibits tropical characteristics and PICs are susceptible to tropical cyclones, high swell events, floods and droughts, which are often driven by El Nino Southern Oscillation (ENSO) circulation patterns (Nunn, 2009). The diversity of the Pacific islands is vast, with high volcanic islands (e.g. Upolu in Samoa) and low atolls islands (e.g. those of Tuvalu and Kiribati). This diversity leads to vastly different levels of vulnerability and resilience to climate change impacts; however, as populations almost always reside along the coast, sea level rise and associated impacts threaten all PICs to some degree (Nunn, 2009).

This paper, based on a year-long research project (see Gero et al., 2010), focuses on Fiji and Samoa as examples of two different PICs, allowing deeper insight into some of the issues occurring in the region. This paper draws upon three community based DRR/CCA projects as case studies to illustrate the various ways in which DRR and CCA are being successfully integrated. This therefore helps to address the recognized gap in the understanding of integration in practice.

\section{Integrating DRR and CCA}

It is now well established that disasters are the result of human actions, not simply natural processes (Helmer and Hilhorst, 2006), and affect the social, political, environmental and economic context (Mercer, 2010). Disaster risk reduction (DRR) is "the systematic development and application of policies, strategies and practices to minimise vulnerabilities, hazards and the unfolding of disaster impacts throughout a society, in the broad context of sustainable development" (United Nations International Strategy for Disaster Reduction (UNISDR), 2004:3). DRR reduces the underlying factors that contribute to human vulnerability. DRR activities are well established at the grassroots level as a method to reduce vulnerability to all hazards (Mercer, 2010) and can involve "hard solutions" such as building infrastructure to certain standards, or "soft solutions", for example education and awareness raising.

Climate change adaptation (CCA) relates to "an adjustment in natural or human systems in response to actual or expected climate stimuli or their effects, which moderates harm or exploits benefit opportunities" (IPCC, 2007). CCA recognises that due to the concentrations of greenhouse gases in the atmosphere, our climate is, and will continue to change, despite efforts to curb emissions (IPCC, 2007). It is therefore necessary to brace ourselves to some extent for coming changes, particularly with regard to vulnerable populations and those likely to experience proportionally more negative impacts. CCA activities also address vulnerability, in this respect in regard to climate (or climate driven) changes. Like DRR, CCA activities are seen as including both hard and soft solutions - e.g. replanting mangroves, coral gardening, reinforcing sea walls, rebuilding or maintaining healthy ecosystems, as well as climate change education and awareness raising. These activities are seen as both DRR and CCA in the Pacific context.

The conceptual and practical similarities and differences between DRR and CCA have been the subject of several recent studies (e.g., Thomalla et al., 2006; Mitchell and van Aalst, 2008; Venton and La Trobe, 2008; Mercer, 2010). These studies found that whilst there are some political and physical distinctions between the scope of each field there is a key area of similarity - a focus on vulnerability reduction and the enhancement of resilience. A number of compelling arguments for the integration of DRR and CCA have been made (Glantz, 2003; O'Brien et al., 2006; Lewis, 2007) and discussions are occurring across scales to make this a reality. Key benefits of integration have been identified as (a) reduced climate related losses through widespread DRR measures; (b) increased efficiency of resources (financial, human and natural, which is crucial when considering aid efficiency) and (c) enhanced effectiveness and sustainability of CCA and DRR approaches (Venton and La Trobe, 2008).

Integration makes particular sense at the community level, since communities themselves do not differentiate between DRR and CCA. Rather, they see risks to their livelihoods and the environment upon which they depend. Local communities have been long adapting to changes to their environment (Kelman et al., 2009; Nunn, 2009) and have as a consequence, developed local coping mechanisms that can be built upon and learned from when considering future climate change adaptation strategies.

\subsection{Why community based DRR and CCA?}

Community based approaches to development are becoming more common place as the development community come to realise the benefits of this approach (Uitto and Shaw, 2006) which recognises and values local culture, conditions and development issues (Ayers and Huq, 2009). Benefits are particularly apparent for initiatives that aim to build resilience to disasters and climate change, as local communities are able to work with development partners and identify risks themselves, thereby addressing vulnerability issues using local knowledge (van Aalst et al., 2008; Mercer et al., 2009).

Within the DRR field, community based approaches to reducing vulnerability have become increasingly popular over the past 20 years (Allen, 2006). In fact, a policy trend 


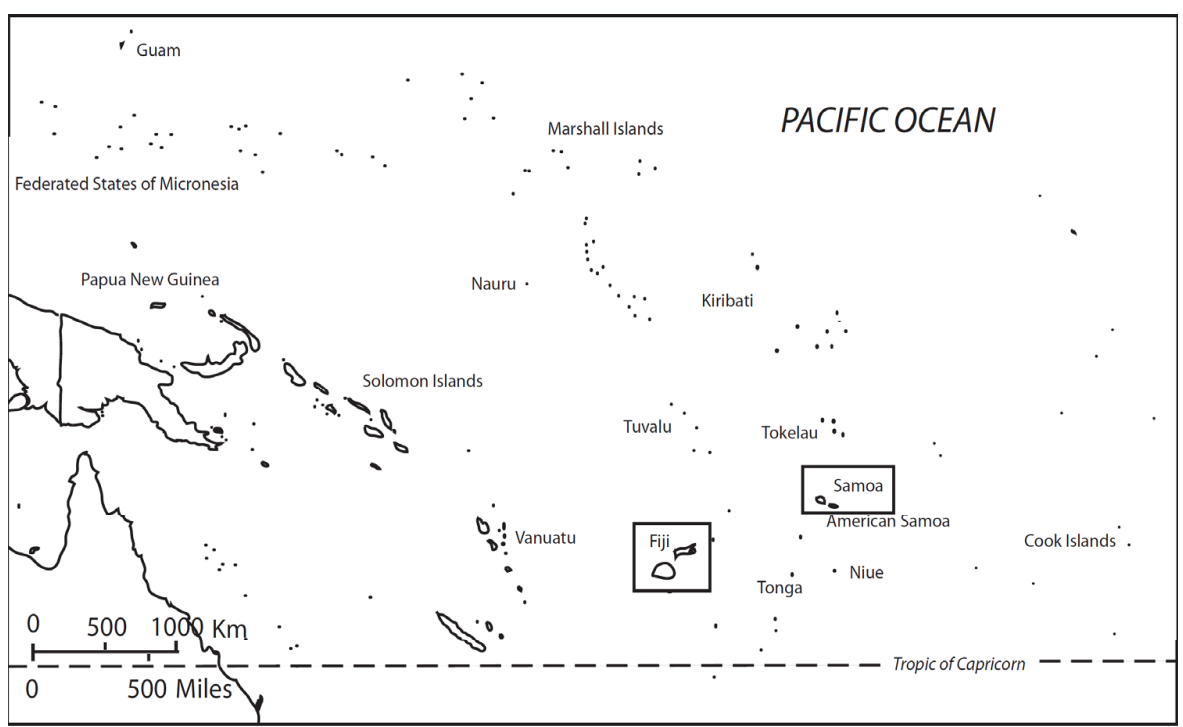

Fig. 1. Location of Fiji and Samoa in the South Pacific context.

towards valuing local knowledge and capacity (Allen, 2006), and instances of putting this policy into practice are emerging, with interesting examples from the Philippines and Bangladesh (see Warner, 2003; Delica-Willison and Willison, 2004; CARE-Bangladesh, 2005). Within the CCA field, there is evidence of increasing interest in community based approaches. This is partly seen in the popularity of international conferences on community based (climate) adaptation, the most recent establishing the Global Initiative on Community Based Adaptation with several global nongovernment organisations (NGOs) cosponsoring the project. Global development agencies such as the United Nations Development Programme (UNDP) have developed Community Based Adaptation projects, while AusAID (Australia's aid program) provides significant funding for Community Based Adaptation initiatives (AusAID, 2009). Further examples of the growing popularity of community based approaches are seen in the increasing number of tools developed to assess community vulnerability and resilience (see Gero et al., 2010 for a list of such tools).

In 2006, Allen, noted that there was a lack of critical analysis of community based approaches with regard to DRR, CCA and vulnerability reduction. Since then, however, a Special Issue of Participatory Learning and Action (2009, Volume 60) has provided valuable and timely reviews of community based approaches to CCA, highlighting the innovative methods communities can employ to develop appropriate adaptation measures. The application of lessons learned is a powerful tool for community based CCA, which is emerging as one of the best approaches to deal with climate change at the local level. This study therefore aims to explore several case studies of community based approaches to DRR and CCA in Fiji and Samoa, to assist the interna- tional community to better understand the outcomes of this emerging approach to community development in the context of integrating DRR and CCA. By focusing on best practice and opportunities for increasing integration, this study contributes to the growing body of practical evidence to further assist in overcoming the challenges associated with integrating DRR and CCA.

\section{Methods}

This research draws upon a range of data collection techniques, including a thorough literature review, along with reviewing web-based networks relating to DRR and CCA globally. This study focused on the Pacific, and in particular Fiji and Samoa (Fig. 1), which were selected as examples of the situation in the Pacific as they present diverse environmental, political, social and cultural backgrounds and correspondingly, different challenges relating to how DRR and CCA are being integrated. The research was informed by two extended periods of field work in Fiji and Samoa, which allowed time to meet with numerous agents and stakeholders in-country to conduct extensive semi-structured interviews. Prior to conducting interviews, researchers obtained ethics clearance from the university's Human Research Ethics Advisory Panel. A total of 47 individuals were interviewed from 29 organisations, which included local NGOs, academic institutions, United Nations (UN) agencies, multilateral and bilateral donors and other key regional organisations. Interview participants provided valuable insight into the challenges faced by practitioners who are working to find practical ways to integrate DRR and CCA at the community level. Recruiting participants for interviews was undertaken with the assistance of information uncovered during an earlier 
phase of the research which involved mapping the organisations and projects associated with Pacific community based DRR and CCA. Whilst in-country, researchers drew upon the snowball sampling technique, which allows for the identification of further participants using a system of referrals, and establishes networks and connections quickly (Atkinson and Flint, 2001). Semi-structured interviews were undertaken, allowing for interviewers to casually guide the general theme of the interview, with answers from participants being descriptive (Jennings, 2005). Recorded interviews were later transcribed and analysed using the software NVivo, a quantitative data analysis tool (see Bazeley, 2007).

To complement data collected through interviews, researchers also participated in disaster simulation exercises that formed part of the Pacific Community focused Integrated Disaster Risk Reduction (PCIDRR) project in Fiji. In addition, researchers participated in the Mekong-Asia Pacific Community Based Adaptation (MAP-CBA) Workshop in Samoa (August 2009), alongside Pacific Islanders working on community programs. Observations during village visits associated with the MAP-CBA initiative were also undertaken in Samoa. These activities were extremely useful in gathering information and talking informally with stakeholders from different backgrounds who are involved in DRR and CCA.

The research developed several case studies of community based DRR and CCA initiatives in Fiji and Samoa. Case studies are used in social research to gain a full understanding of a case in depth, in its natural setting and taking into account complexity and context (Punch, 2005). Case studies presented here are "instrumental case studies" (Punch, 2005), used to provide insight into the reality of practice of community based DRR and CCA in the Pacific. Through the case studies, which included extensive interviews with various stakeholders involved in the projects, characteristics of successful initiatives and common themes relating to the challenges of integrating DRR and CCA were identified. These projects, located in Fiji and Samoa, were selected as they provided examples of the diverse ways in which DRR and CCA are addressed. Multiple agents, actors and stakeholders involved in these case studies were interviewed to develop a full picture of each project, including the aims and objectives, implementing and partner organisations, donor agency, location and associated activities. Details of the case studies are provided in Table 1, with the three projects described in this paper in detail presented first.

\section{Community based DRR and CCA projects}

A number of community based DRR and CCA projects are currently underway in Fiji and Samoa. Presented below are three case studies of projects currently taking place, that each integrate DRR and CCA to differing degrees. The projects differ in their approaches, funding sources, partnerships and objectives, and are reflective of the breadth of community based projects being implemented in the Pacific.

\subsection{Community Based Health and First Aid: Samoa Red Cross}

Red Cross is known internationally for its work on DRR and CCA, particularly via the International Federation of the Red Cross/Red Crescent Societies (IFRC) and the Red Cross/Red Crescent Climate Centre (see for example IFRC, 2006 and Red Cross, 2007) along with the ongoing work of national societies. Given Samoa's history of natural disasters, the Samoa Red Cross Society has long been involved in disaster preparedness and response and is an active member of Samoa's Disaster Advisory Committee (DAC), a group chaired by the Samoan government's Disaster Management Office (DMO) and the Ministry of Natural Resources and Environment (MNRE).

In addition to their DRR experience, Samoa was selected by the IFRC in 2002 as a pilot country for the inclusion of CCA in community programs. CCA has therefore been integrated into the approach developed for DRR, as noted by an interview participant from Red Cross: "Disaster preparedness and response are part of the Red Cross's traditional programs. Now with climate change coming up we are integrating these things together because we have been very active in these areas". Given the similarities between DRR and CCA (which were recognised by Samoa Red Cross staff), and the fact that the impacts of disasters are anticipated to be exacerbated by future climate change, there is strong motivation to integrate CCA into DRR projects.

The Samoa Red Cross Society has a relatively long history of community based development programs in operation. The current approach, Community Based Health and First Aid (CBHFA) project, is a nation-wide, holistic and creative community program that addresses the specific needs of communities, as an interview participant explains, "We (Red Cross) took the CBHFA to the community we looked at their perception of hazards. We have seen a lot of advantage in taking things together (to communities), not only targeting the same audience also resource sharing. So it helps with costs. We are not a rich organisation but we can work with others and share resources." The element of "taking things together" refers to both various aspects of Red Cross programs, as well as working alongside representatives from government and NGOs with expertise in risk reduction.

The main aim of the CBHFA program is to holistically reduce vulnerability of local communities based on the specific needs of local people. Via a "soft solution" approach, and one recognizing existing and future (climate change driven) vulnerability, it utilises the Red Cross Vulnerability and Capacity Assessment (VCA) tool, a participatory tool designed to allow communities to identify their own vulnerabilities and capacities to take an active role in developing measures to reduce vulnerabilities and enhance capacities. The VCA 
Table 1. DRR and CCA case study information.

\begin{tabular}{|c|c|c|c|c|c|}
\hline Project/Initiati & Donor & Location & $\begin{array}{l}\text { Implementing } \\
\text { Agency/ } \\
\text { Organisations }\end{array}$ & Activities & Aims and objectives \\
\hline $\begin{array}{l}\text { Samoa Red } \\
\text { Cross Com- } \\
\text { munity Based } \\
\text { Health and } \\
\text { First Aid } \\
\text { (CBHFA) } \\
\text { Program }\end{array}$ & $\begin{array}{l}\text { International } \\
\text { and National } \\
\text { Red Cross } \\
\text { societies }\end{array}$ & $\begin{array}{l}\text { Samoa (nation- } \\
\text { wide) }\end{array}$ & $\begin{array}{l}\text { Samoa } \\
\text { National } \\
\text { Red Cross } \\
\text { Society and } \\
\text { government } \\
\text { partner } \\
\text { ministries }\end{array}$ & $\begin{array}{l}\text { Education and community } \\
\text { awareness relating to the spe- } \\
\text { cific needs of the community, } \\
\text { using Red Cross's Vulnerabil- } \\
\text { ity and Capacity Assessment } \\
\text { (VCA) tool. Specific atten- } \\
\text { tion paid to disaster and cli- } \\
\text { mate change related issues and } \\
\text { needs. Inclusion of government } \\
\text { ministries to allow for follow up } \\
\text { of additional activities. }\end{array}$ & $\begin{array}{l}\text { To assess the specific vulnera- } \\
\text { bilities of the village and de- } \\
\text { velop a targeted response to ed- } \\
\text { ucate people in ways to over- } \\
\text { come and become more aware } \\
\text { of the risks in their daily lives. }\end{array}$ \\
\hline $\begin{array}{l}\text { Navua Local } \\
\text { Level Risk } \\
\text { Management }\end{array}$ & $\begin{array}{l}\text { UNDP Pacific } \\
\text { Centre }\end{array}$ & Navua, Fiji & $\begin{array}{l}\text { UNDP, } \\
\text { SOPAC, Red } \\
\text { Cross, National } \\
\text { Disaster Man- } \\
\text { agement } \\
\text { Office (NDMO) }\end{array}$ & $\begin{array}{l}\text { Education and community } \\
\text { awareness for pre-existing } \\
\text { early warning flood system in } \\
\text { addition to multi-stakeholder } \\
\text { involvement in long term com- } \\
\text { munity awareness activities. }\end{array}$ & $\begin{array}{l}\text { Using the Local Level Risk } \\
\text { Management (LLRM) } \\
\text { approach, capacity building } \\
\text { with the community, NGOs and } \\
\text { local authorities in terms of risk } \\
\text { sensitisation and disaster risk } \\
\text { sensitive development projects. }\end{array}$ \\
\hline $\begin{array}{l}\text { GEF-SGP } \\
\text { Community } \\
\text { Based } \\
\text { Adaption } \\
\text { (CBA) }\end{array}$ & GEF/AusAID & $\begin{array}{l}\text { Global: } 10 \text { pi- } \\
\text { lot countries in- } \\
\text { cluding Samoa }\end{array}$ & $\begin{array}{l}\text { Small Grants } \\
\text { Programme } \\
\text { (SGP) and } \\
\text { United Nations } \\
\text { Development } \\
\text { Programme } \\
\text { (UNDP) }\end{array}$ & $\begin{array}{l}\text { Enhancing community } \\
\text { resilience to climate } \\
\text { change via community educa- } \\
\text { tion and awareness, coupled } \\
\text { with "hard solutions" such } \\
\text { as shoreline protection. }\end{array}$ & $\begin{array}{l}\text { Enhancing community } \\
\text { resilience and the ecosystems } \\
\text { upon which they depend via } \\
\text { a "results based approach" } \\
\text { including community adapta- } \\
\text { tion priorities (United Nations } \\
\text { Development Programme } \\
\text { (UNDP), 2008). }\end{array}$ \\
\hline $\begin{array}{l}\text { Building } \\
\text { Disaster } \\
\text { Response and } \\
\text { Preparedness } \\
\text { in the Pacific }\end{array}$ & AusAID & $\begin{array}{l}\text { Fiji, Samoa, } \\
\text { Kiribati, } \\
\text { Vanuatu }\end{array}$ & $\begin{array}{l}\text { Caritas Samoa } \\
\text { and Australia, } \\
\text { Caritas Oceania } \\
\text { and Pacific }\end{array}$ & $\begin{array}{l}\text { Education and community } \\
\text { awareness with the aim being } \\
\text { to change behaviour to incorpo- } \\
\text { rate better preparedness for dis- } \\
\text { asters in everyday living. }\end{array}$ & $\begin{array}{l}\text { To raise awareness and educate } \\
\text { key Catholic people in disaster } \\
\text { risk reduction in order to pass } \\
\text { this information on to the wider } \\
\text { community (Caritas Australia, } \\
\text { 2008). }\end{array}$ \\
\hline
\end{tabular}

is undertaken as a means to gather information at the household level about vulnerability, particularly to disasters, and also equally about people's capacity to deal with these types of events (IFRC, 2006). An interview participant notes: "We found it was really necessary for us to do VCA in every community that we work with. I think its a tremendous tool to work with, with repsect to going to every household in the community."

The CBHFA program is implemented with the support of Samoa's powerful Church network at the village level, and incorporates gender considerations with its approach by ensuring participation from both men and women, and girls and boys (see Lane and McNaught, 2009 for details of gender issues in the Pacific). Over a two week period, the project team (comprised mainly of volunteers) use the VCA to assess the specific vulnerabilities and capacities of the village and develop a targeted response to educate people in ways to overcome and become more aware of the risks in their daily lives. The project team also assist with the interpretation of meteorological information, since different villages have various vocabulary and interpretation of north, south, east and west (van Aalst, 2008). The team's response to the village's specific needs is often creative, and may include drama, puppetry and skits to educate the community about sensitive issues, as noted by an interview participant, "From the VCA analysis, we found out there are needs and these needs turn into the scripts. For example, if their children have not been immunised, they will talk about this. Or even do up skits that address the problem."

The CBHFA initiative also works with government ministries, including the DMO, to combine efforts and deliver a holistic and well targeted response to reducing vulnerability at the community level. Government ministries involved include Ministry of Natural Resources and Environment, Ministry of Agriculture and Fisheries, Ministry of Health, National Health Services and Ministry of Public Works and 
Table 1. Continued.

\begin{tabular}{|c|c|c|c|c|c|}
\hline $\begin{array}{l}\text { Project/ } \\
\text { Initiative }\end{array}$ & Donor & Location & $\begin{array}{l}\text { Implementing } \\
\text { Agency/ } \\
\text { Organisations }\end{array}$ & Activities & Aims and objectives \\
\hline $\begin{array}{l}\text { WWF Coastal } \\
\text { Resilience }\end{array}$ & GEF & $\begin{array}{l}\text { Fiji, India, } \\
\text { East and West } \\
\text { Africa }\end{array}$ & $\begin{array}{l}\text { WWF, USP, } \\
\text { SOPAC, Fiji } \\
\text { Met Service }\end{array}$ & $\begin{array}{l}\text { Community consultation cou- } \\
\text { pled with scientific evidence } \\
\text { to devise strategy to manage } \\
\text { coastal mangrove ecosystems. }\end{array}$ & $\begin{array}{l}\text { To develop a "generalisable" } \\
\text { approach to addressing coastal } \\
\text { resilience across similar habi- } \\
\text { tats (i.e. mangroves), and main- } \\
\text { taining intact mangrove sys- } \\
\text { tems that support the connec- } \\
\text { tivity between mangroves and } \\
\text { coral reefs. }\end{array}$ \\
\hline $\begin{array}{l}\text { Samoa } \\
\text { Disaster Risk } \\
\text { Reduction } \\
\text { and Aware- } \\
\text { ness Work- } \\
\text { shops }\end{array}$ & $\begin{array}{l}\text { UNESCO, } \\
\text { SOPAC, World } \\
\text { Bank }\end{array}$ & Samoa & $\begin{array}{l}\text { NDMO, mul- } \\
\text { titude of other } \\
\text { government } \\
\text { agencies, } \\
\text { NGOs, Red } \\
\text { Cross }\end{array}$ & $\begin{array}{l}\text { Education and community } \\
\text { awareness relating to } \\
\text { disasters. Follow up activities } \\
\text { with the assistance of gov- } \\
\text { ernment ministries, including } \\
\text { potential "hard solutions" de- } \\
\text { pending on the needs of the } \\
\text { community. }\end{array}$ & $\begin{array}{l}\text { To strengthen village under- } \\
\text { standing of current vulnerabil- } \\
\text { ity and capacity, risk reduc- } \\
\text { tion measures and consequently } \\
\text { formulating a village Response } \\
\text { Plan Booklet for all households. } \\
\text { To also have a village simula- } \\
\text { tion to test the response of the } \\
\text { village to a disaster. }\end{array}$ \\
\hline $\begin{array}{l}\text { Pacific } \\
\text { Community- } \\
\text { Focused } \\
\text { Integrated } \\
\text { Disaster Risk } \\
\text { Reduction } \\
\text { (PCIDRR) }\end{array}$ & $\begin{array}{l}\text { National Council } \\
\text { of Churches } \\
\text { (NCCA), Aus- } \\
\text { AID }\end{array}$ & $\begin{array}{l}\text { Fiji, Solomon } \\
\text { Islands, Tonga, } \\
\text { Vanuatu }\end{array}$ & $\begin{array}{l}\text { PCIDRR } \\
\text { Team, NCCA, } \\
\text { NDMO, } \\
\text { Adventist } \\
\text { Development } \\
\text { and Relief } \\
\text { Agency } \\
\text { (ADRA) }\end{array}$ & $\begin{array}{l}\text { Disaster management } \\
\text { training, development } \\
\text { of Community Disaster Plan } \\
\text { and disaster response practice } \\
\text { via simulation exercise. }\end{array}$ & $\begin{array}{l}\text { To create better awareness and } \\
\text { understanding of disaster risks } \\
\text { at the community level and to } \\
\text { identify means to enhance re- } \\
\text { silience to these risks. Creation } \\
\text { of Community Disaster Plan, } \\
\text { training of people in village } \\
\text { in disaster response (National } \\
\text { Council of Churches Australia } \\
\text { (NCCA), 2007). }\end{array}$ \\
\hline $\begin{array}{l}\text { Climate } \\
\text { Change and } \\
\text { Food Security }\end{array}$ & FAO & Samoa & $\begin{array}{l}\text { Women in } \\
\text { Business for } \\
\text { Development } \\
\text { Inc (WIBDI) }\end{array}$ & $\begin{array}{l}\text { Education and community } \\
\text { awareness relating to food } \\
\text { security, nutrition and sustain- } \\
\text { able livelihoods. Provision of } \\
\text { seeds and piggeries as start-up } \\
\text { resources for identified family } \\
\text { in need of assistance. }\end{array}$ & $\begin{array}{l}\text { To target the mostvulnerable } \\
\text { people in communities and } \\
\text { assist them in developing their } \\
\text { own sustainable livelihoods. } \\
\text { The approach includes assisting } \\
\text { families reduce their depen- } \\
\text { dence on remittances from } \\
\text { family members overseas by } \\
\text { becoming self-sufficient and } \\
\text { growing their own food, and } \\
\text { possibly growing enough to } \\
\text { provide an additional source of } \\
\text { income. }\end{array}$ \\
\hline
\end{tabular}

Infrastructure. In addition to government ministries, the CBHFA also works with NGOs such as Women In Business Development Inc (WIBDI), who work with organic farmers on developing sustainable livelihoods for Samoan families. As noted by an interview participant: "The second week is when we present everything the Red Cross does. We can even say we have these techncial people they can ask (specific questions). People that come with us include Agriculture, Health, Meteorological people, Public Works and building codes. Whatever issues are in that village." The inclusion of these additional stakeholders allows for "in kind" support, thus an efficient and effective way to share costs of implementation.
Project partners are well versed in key national baseline information, such as the Coastal Infrastructure Management (CIM) Plans (see Daly et al., 2010), which provide information on coastal vulnerability and the National Adaptation Plan for Action (NAPA, see Ministry of Natural Resources and Environment (MNRE), 2005), which describes Samoa's vulnerability and response to climate change. As such, the CBHFA is well placed to cover gaps in community needs regarding DRR and CCA. 


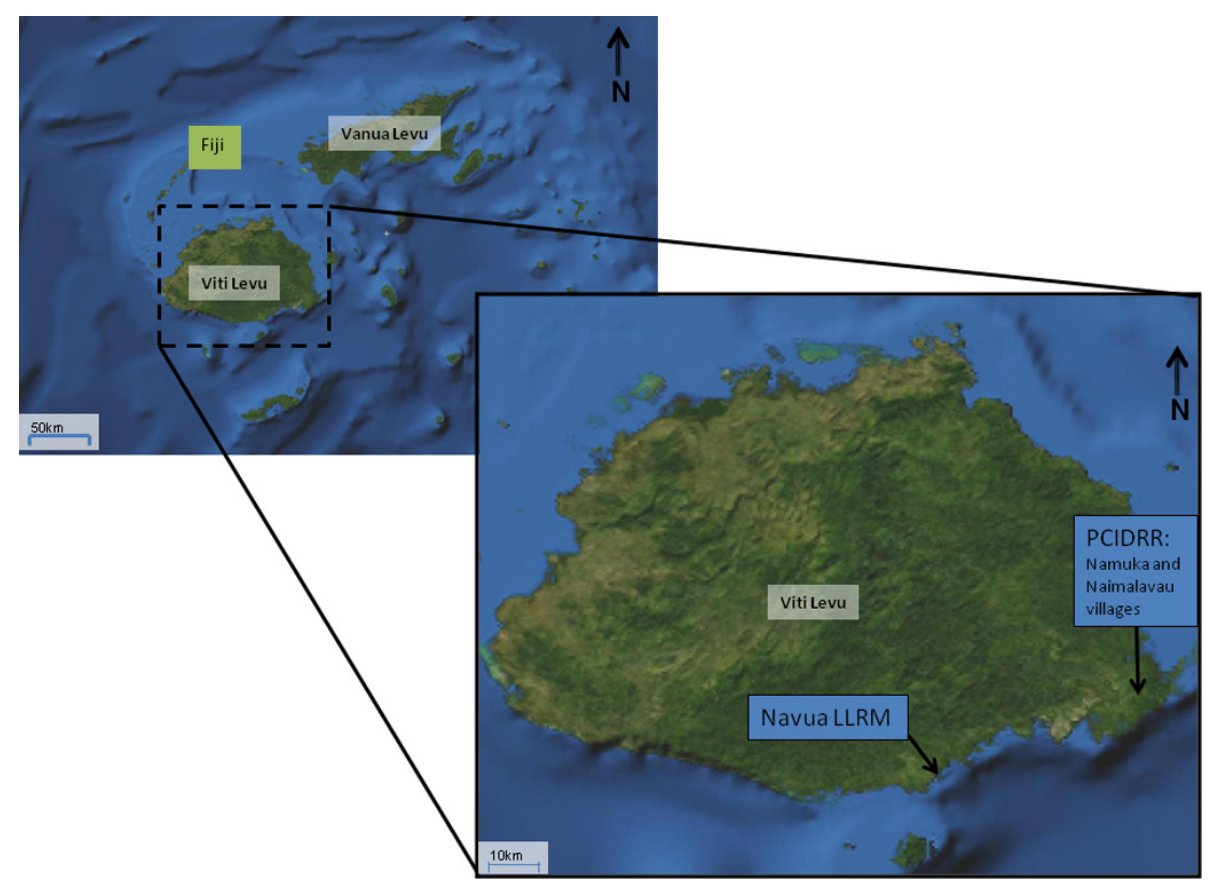

Fig. 2. Location of Navua, Fiji.

\subsection{Navua Local Level Risk Management (LLRM) project}

Local Level Risk Management (LLRM) is a tool used to address risk by engaging with local organisational and institutional structures (United Nations Development Programme, 2006). This approach is used in Navua, Fiji (Fig. 2), which is an area susceptible to severe flooding. Recent flood events in 2003 and 2004 resulted in extensive damage to crops, livestock, houses, roads and bridges with thousands of people losing their homes and belongings (Mataki et al., 2006). The aim of this United Nations Development Programme (UNDP) two year project was to further develop the community's understanding of the pre-existing flood early warning system (Fig. 3). The LLRM's "soft solution" approach also seeks to work closely with the community, local organisations and various levels of government to enhance the understanding of natural hazards to the region, as well as the linkages between development and disaster risk in the Navua area. The approach is therefore taking practical steps to apply a DRR approach in light of existing development issues. It aims to address current risk based upon historical models of hazard impact, thus draws on mainly traditional DRR approaches.

The LLRM approach suits the Pacific context as it values relationship building, which was noted by an interview participant: "Relationships are more important here (in the Pacific) than elsewhere - (we) need to stay in the community and build the trust. It takes more here. (We) have to understand the culture and don't come in as a stranger."
Additional outputs included developing processes for risk sensitising local government development programming, and strengthening the capacity of communities so as to be a part of decision making regarding risk sensitive development (United Nations Development Programme, 2007).

Many of the key stakeholders associated with disaster risk management (DRM) in Fiji and the Pacific region were involved in the project. This includes the Fiji Red Cross Society, with technical input from their global counterpart IFRC, Pacific Islands Applied Geoscience Commission (SOPAC, who initiated the early warning system in conjunction with the Fiji Public Works (Hydrology Division) and Fiji Meteorological Service), the National Disaster Management Office (NDMO) and The Asia Foundation/Office for Foreign Disaster Assistance (TAF/OFDA) for DRM training assistance. The Bureau for Crisis Prevention and Recovery (BCPR, a UNDP body) provided the bulk of funding and technical assistance in devising DRR strategies for implementation. The Global Environment Facility (GEF) also funded a follow up initiative. The involvement of multiple stakeholders allows for additional skills and experience to be included in implementation, and often, a resulting skills transfer. Cost sharing is an additional benefit, as local organizations provide support as a form of "in kind" assistance.

At the local level, individuals such as the Turaga ni Koro (elected village head representing the traditional government system at village level) and Village Chief (hereditary village leader) were represented, as well as Civil Society Organisations (CSOs) and the Rural Local Authority, the ruling body for the Navua township. As a result of the 


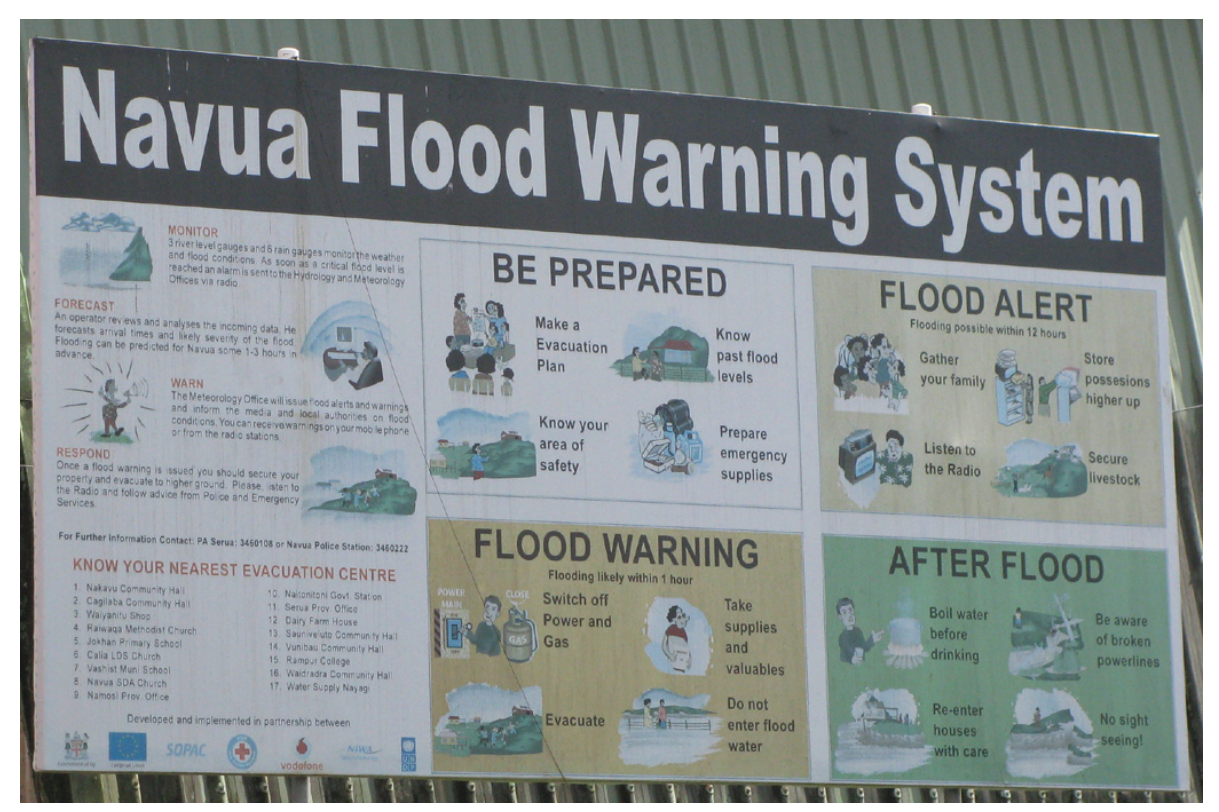

Fig. 3. Navua sign describing early warning system for flood.

collaboration amongst stakeholders, an interview participant noted: "Navua had a good collaboration of agencies and organisations involved. The project has evolved with sound justification on where it should go and how it should go".

The Navua LLRM project was intended to complement efforts at the national level to mainstream DRM by the Pacific Disaster Risk Management Partnership Network via the implementation of a National Action Plan (NAP) in Fiji which is being undertaken by SOPAC. NAPs set out disaster risk management actions at the national level. The Navua LLRM project also complements activity at the regional level, including the Disaster Risk Reduction and Disaster Management Framework for Action, 2005-2015 (SOPAC, 2005) which mirrors the international Hyogo Framework for Action 2005-2015 (International Strategy for Disaster Reduction, 2005) for the Pacific regional level.

The LLRM approach incorporated the Vulnerability and Capacity Assessment (VCA), which is participatory by nature, requiring community input in describing community practices, systems and norms that relate to DRR, and also their vulnerability to hazards and risks in the community (IFRC, 2006). The Fiji Red Cross Society, with support from the IFRC, was instrumental in implementing this aspect of the project. Partner organisations such as the NDMO and UNDP, were also keen to be involved as the tool assists in reaching to the community level and involving them in meaningful ways. Workshops, training sessions and other forms of communicating information formed additional activities that involved partner organisations, e.g. TAF/OFDA and SOPAC.

Working with partners such as the Fiji Red Cross Society enabled the project to be implemented by people who understand what it is to work in DRR in the Pacific. Red Cross volunteers are experienced in community engagement and therefore can penetrate to the level where the greatest difference can be made, i.e. at the local scale. Technical language and terminology from development agencies can sometimes hinder the success of a development project. For example, there is no Fijian word for "vulnerability" - the closest word translates to "weakness". Using the local language and appropriate phrases can make a significant difference in how the community perceives outsiders coming in to implement development work. This project succeeded in that sense by using local people where possible.

Although drawing on a more DRR focused approach, CCA features explicitly in an activity identified via the VCA process. This activity involved mangrove replanting in a neighbouring village near to the Navua river mouth, and funded via a grant from the GEF through the Small Grants Program to address a CCA issue involving mangroves. Thus while the majority of the Navua LLRM project would be classed as DRR, CCA is incorporated in a subtle and implicit sense.

\subsection{Samoa Community Based Adaptation (CBA)}

The Global Environment Facility (GEF) is the financial mechanism for the United Nations Framework Convention on Climate Change (UNFCCC), tasked to assist countries with on-the-ground action to cope with climate change impacts (Global Environment Facility, 2009). The Community Based Adaptation (CBA) Project is one such initiative, developed as a pilot project for 10 developing countries, including Samoa. The initiative, which is implemented by the UNDP, aims to enhance community resilience and the 


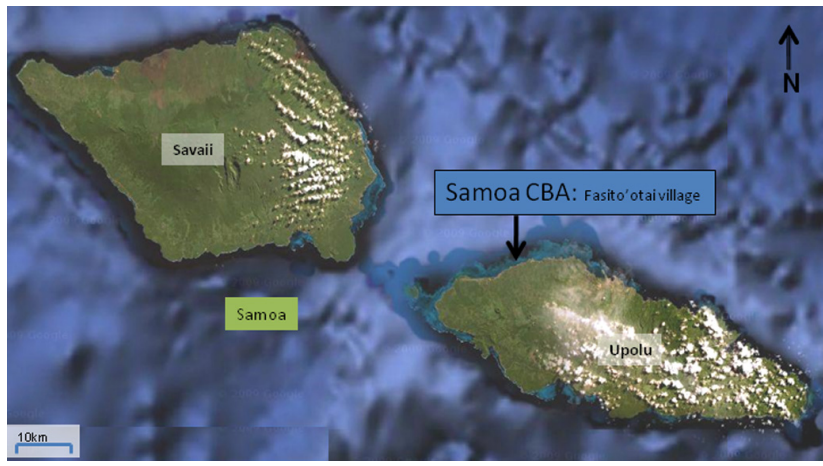

Fig. 4. Location of Fasit'otai village, Samoa.

ecosystems upon which they depend (Global Environment Facility, 2009).

The specific goal of the Samoa CBA initiative, which is located in Fasito'otai (Fig. 4) and co-funded by AusAID, is to enhance the adaptive capacity of the village of $\mathrm{Fa}$ sito'otai and reduce the vulnerability of the mangrove and coral reef ecosystem to the risks associated with current and future climate change impacts. Project activities have a future perspective, and include climate change education and awareness raising, construction of shoreline protection and replanting of mangroves to stop coastal erosion. While the outputs were locally driven, they were adjusted so as to fulfill the requirements and obligations of the global CBA approach, which includes addressing gaps in current information, as noted by an interview participant: "Local information isn't there so that's why the GEF CBA is here to try and fill that gap."

CBA projects need to align to local culture, needs and capacity, as well as existing strategies at the local, national and regional level. For Samoa, that includes the National Adaptation Plan for Action (NAPA), Coastal Infrastructure Management (CIM) Plans and the Climate Risk Profile (K. Petrini, personal communication, 2009). Figure 5 provides an example of cultural practice being incorporated into a project workshop, recognizing the importance of respecting local cultural protocols in developing trust between the community and project implementers.

The CBA approach is described by the GEF as "bottomup", recognising the need for flexibility in implementation technique and the strategic approach taken, depending on the location and needs of the community (Global Environment Facility, 2009). For Samoa and the village of Fasito'otai, this approach is exemplified by the fact that the concept for the village project was identified by the village pastor and from there, scaled up as a CBA project. Fasito'otai is fortunate to have local experts involved in the project's development and implementation, including an Engineer who consults for the Fasito'otai CBA project. An interview participant explains: "I think it was the pastor who originally came up with the idea - he lives in the village, he knows the history of the

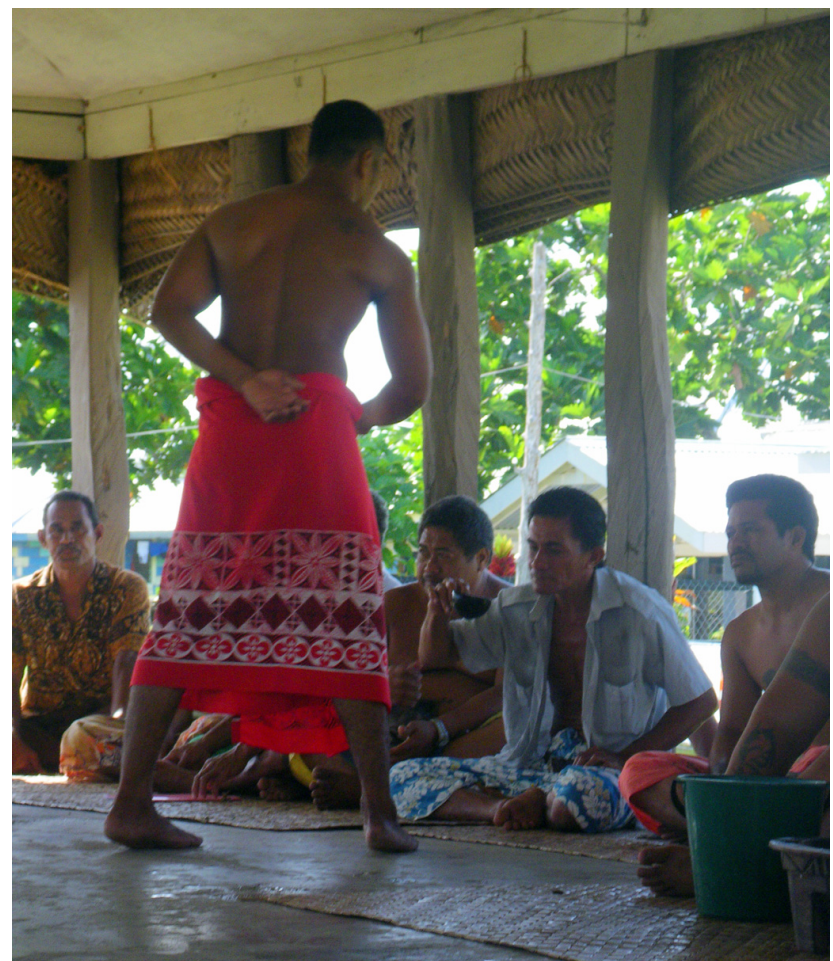

Fig. 5. Traditional ceremony, incorporated into CBA workshop proceedings.

village. He rallied the matais (chiefs) and because he runs a lot of the community based (programs) - the youth, the church, Sunday School."

The CBA approach recognises the importance of targeting local communities for CCA initiatives, since villages such as Fasito'otai may the first to face the consequences of climate change, while at the same time, be least able to adapt to the changes (United Nations Development Programme (UNDP), 2008). This is not to underestimate the resilience of small communities who have been coping with natural climate variability for centuries. The CBA initiative provides communities with assistance to boost their adaptive capacity so as to be able to maintain sustainable livelihoods which are heavily dependent on the local environment, as noted by an interview participant: "Samoa's requirements are that there has to be a capacity building and educational piece involved in the project proposal. Raising awareness of climate change in the village. It's trying to talk about what climate change actually is."

Global to local stakeholders are involved in this project. From the local level, the communities themselves represent a significant agent, with sub-groups and key people involved in the project. This includes the Church, the Council of Chiefs, the Women's Committee and the Development Committee. At the national level, government ministries such as the Ministry of Natural Resources and Environment (MNRE) and the Ministry of Works are involved, as well as the 
GEF-Small Grants Program Secretariat, the UNDP Country Team, the National Steering Committee and the Technical Review Committee. At the regional level, SOPAC, Pacific Regional Environment Program (SPREP), academic institutions and UNDP Technical Advisors are involved. Finally, GEF, AusAID and UNDP represent global level agents and stakeholders. This collection of local to regional and global stakeholders allows for input and expertise addressing local knowledge and inclusion of traditional coping mechanisms, as well as best practice and scientific CCA expertise from global partners.

The links to DRR can be seen via the inclusion of the Disaster Management Office (DMO) in the Technical Review Committee. However, a representative from the DMO notes that the links could perhaps be stronger, not only with this particular project, but in general: "I am part of the Technical Review Committee. I try to ensure its taking into account proper risk analysis because that's still very weak in Samoa."

\section{Best practice and opportunities for integration}

These three case studies provide different examples of the ways in which community based initiatives are tackling DRR and CCA in the Pacific. From these case studies four key elements have been identified that highlight best practice and opportunities to achieve genuine integration between DRR and CCA in community based projects. These are described below.

\subsection{Taking an holistic approach}

The first is the approach drawn upon by the Samoa Red Cross CBHFA project to reduce vulnerability by holistically addressing community development and the specific needs of the target audience. The VCA is a useful tool to highlight not only the needs of the community, but also the capacity, skills, experience and knowledge that exists within communities. Pacific Islanders have been long coping with natural disasters, as most of the population reside close to the sea and interact daily with the environment for their food and livelihoods (Nunn, 2009). Drawing upon this local knowledge and developing an approach that not only addresses disaster and climate risk but all aspects of vulnerability can result in a success and sustainable community initiative. Doing so in innovative and creative ways further illustrates how the project has been fine tuned to address sensitive issues that are, in the Samoan context, difficult to discuss in normal circumstances. This approach is described by an interview participant, who notes, "We took the CBHFA to that community - we didn't want to go specifically for HIV - so we just took everything, including the VCA we looked at their perception of hazards."

\subsection{Using multi-sectoral and multi-stakeholder teams (and expertise)}

The second element of best practice is the use of multisectoral and multi-stakeholder project teams. By drawing upon the skills and experience of individuals and organisations with expertise in DRR and CCA related disciplines, it is possible to develop a collaborative and cooperative initiative. All case studies were successful in drawing on the skills and expertise of related organisations, and this is recommended to be an elements of other community based projects, as it can particularly useful in cost sharing and capacity building. Doing so also acts to mainstream DRR and CCA across various sectors of society.

\subsection{Genuine community participation}

Integrating DRR and CCA in community projects can be better achieved with genuine community participation. This is identified as the third aspect of best practice, since communities themselves do not differentiate between risks associated with either DRR or CCA, thus having genuine community input will result in a robust and comprehensive treatment of risk. Often phrased as an "all hazards approach", addressing underlying causes of vulnerability with active participation of community members and groups can result in sustainable initiatives. All three of the case studies described here present elements of community participation as they recognise the far reaching benefits of doing so. Furthermore, case studies which encourage full participation from the community from the outset appear to be the most sustainable. For example, the idea behind the Samoa CBA initiative came from within the village. Conversely, projects which include a token amount of community participation, or do not include the community in project design, approach and implementation are less likely to be sustained beyond the duration in which funding is available.

\subsection{Avoiding fragmentary policy approaches}

Lastly, an obstacle to integrating DRR and CCA is seen via the fragmentation of policy and legislation from the local to the global level. Policy frameworks for DRR and CCA remain, for the most part, entirely separate as illustrated in Fig. 6. This fragmentation of the "architecture" that frames and underpins DRR and CCA policy is a phenomenon that has been highlighted as an area of concern for policy makers, particularly relating to climate change (Biermann et al., 2007). In fact, weak institutional structure has been described as a bottleneck to effective management (Nicholls, 2001). Integrating DRR and CCA, practically speaking, is made all the more difficult as projects must often be framed according to these institutions, policies and legislative guidelines. This creates a barrier for DRR and CCA practitioners trying to develop and implement holistic and strategically 


\begin{tabular}{|c|c|c|}
\hline \multicolumn{2}{|c|}{ DISASTER RISK REDUCTION } & CLIMATE CHANGE ADAPTATION \\
\hline $\begin{array}{l}\text { Yokohama Strategy and } \\
\text { Plan of Action (1994) }\end{array}$ & \multirow{9}{*}{ 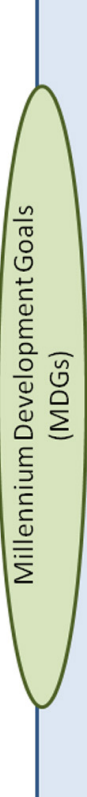 } & $\begin{array}{c}\text { United Nations } \\
\text { Framework Convention on } \\
\text { Climate Change (UNFCCC) }\end{array}$ \\
\hline $\begin{array}{l}\text { Hyogo Framework for } \\
\text { Action (2005-2010) }\end{array}$ & & Kyoto Protocol \\
\hline \multirow{2}{*}{$\begin{array}{c}\text { Pacific Disaster Risk } \\
\text { Reduction and Disaster } \\
\text { Management Framework } \\
\text { for Action (2005-2010) }\end{array}$} & & $\begin{array}{c}\text { Bali Action Plan and Road } \\
\text { Map (2007) }\end{array}$ \\
\hline & & $\begin{array}{c}\text { Nairobi Work Program } \\
(2005-2010)\end{array}$ \\
\hline National Adaptation Plan & & $\begin{array}{c}\text { Pacific Regional } \\
\text { Framework on Climate } \\
\text { Change }\end{array}$ \\
\hline $\begin{array}{l}\text { National Disaster } \\
\text { Management Act }\end{array}$ & & National Communications \\
\hline $\begin{array}{c}\text { National Disaster } \\
\text { Committee Agendas }\end{array}$ & & $\begin{array}{c}\text { National Adaptation Plan } \\
\text { of Action (NAPA) } \\
\end{array}$ \\
\hline Local Disaster Committee & & $\begin{array}{c}\text { National Greenhouse Gas } \\
\text { Abatement Strategies }\end{array}$ \\
\hline Agendas & & $\begin{array}{c}\text { Climate Change Country } \\
\text { Team Agendas } \\
\end{array}$ \\
\hline
\end{tabular}

Fig. 6. Global to local DRR and CCA policy frameworks.

Table 2. Best practice methods for integration.

\begin{tabular}{l}
\hline Best Practice methods \\
\hline Holistic approach to vulnerability reduction \\
\hline Use of multi-sectoral and multi-stakeholder approach \\
\hline Ensure genuine community participation \\
\hline Overcome fragmented policy frameworks \\
\hline Focus on both "hard" and "soft" solutions to vulnerability reduction \\
\hline $\begin{array}{l}\text { Draw upon traditional knowledge where possible and where possible, } \\
\text { link local observations of climate change to scientific knowledge }\end{array}$ \\
\hline $\begin{array}{l}\text { Practicing of roles and responsibilities for disaster response, since } \\
\text { severe weather may become more frequent and intense with climate change }\end{array}$ \\
\hline
\end{tabular}

placed activities that reduce vulnerability and enhance resilience to risk. For example, given its climate change focus, the CBA project follows the policy chain on the right, while Navua LLRM, follows that of the left.

Projects that recognise and consequently aim to overcome this fragmented architecture are therefore seen as best practice in terms of integrating DRR and CCA. The CBHFA project succeeds in doing so by locally addressing the needs of communities. By strategically including relevant stakeholders and expertise from government and NGOs, relevant policy is inherently included, but without needing to bias or favour a particular framework over another. For organisations or projects explicitly targeting either DRR or CCA, or backed by donors such as the GEF (which explicitly fund cli-
Table 3. Recommendations for overcoming obstacles to integration.

\begin{tabular}{|c|}
\hline Recommendations for overcoming obstacles to integration \\
\hline $\begin{array}{l}\text { Focus on village specific vulnerabilities and capacity and highlight } \\
\text { the impact on livelihoods }\end{array}$ \\
\hline $\begin{array}{l}\text { Ensure partnership with, and inclusion of, relevant organisations from } \\
\text { project inception }\end{array}$ \\
\hline Consider gender roles and cultural needs of target communities \\
\hline $\begin{array}{l}\text { Look for opportunities to integrate and be open minded to collaborate } \\
\text { with relevant initiatives }\end{array}$ \\
\hline $\begin{array}{l}\text { Inclusion of capacity building via education and awareness raising } \\
\text { ensures project sustainability when funding ceases to be available }\end{array}$ \\
\hline $\begin{array}{l}\text { Use local language and local people to implement and facilitate } \\
\text { projects where possible. This will ensure local ownership and a focus } \\
\text { on locally significant issues }\end{array}$ \\
\hline $\begin{array}{l}\text { Minimise the use of technical language and jargon, and ensure local language } \\
\text { is used wherever possible }\end{array}$ \\
\hline
\end{tabular}

mate change projects) it becomes more difficult. The recommendation, however, is to look for opportunities to integrate and be open minded to relevant initiatives to learn from and build upon. Tables 2 and 3 summarise our findings relating to best practice methods and recommendations to overcome obstacles to integration. 


\section{Conclusions}

Community based projects such as those described in this paper have impediments to integrating DRR and CCA via donor requirements, partner organisations and underlying policy frameworks. Opportunities do exist, however, to assist in bringing together these two often overlapping fields. Developing an awareness of both DRR and CCA related initiatives, organisations and policy arrangements will reduce duplications of efforts, and thus contribute to aid effectiveness. Not only will existing organisations be able to share relevant experiences and lessons learned (perhaps from CCA to DRR practitioners, or vice versa), they will also be aware of gaps and future needs. Opening the dialogue between these agents also serves to initiate, develop and maintain the good relationships that are crucial in becoming part of the institutional architecture that operates in the Pacific. Furthermore, by addressing vulnerability at the local level in a holistic sense, the community will benefit by receiving a well targeted program, and DRR and CCA will inherently be incorporated alongside risks such as health, nutrition, disease and other livelihood issues. By sharing lessons learned and best practice, as well as sharing practices that perhaps were not successful, organisations can better utilise the funds that are available to achieve advances in development in the Pacific.

Acknowledgements. This work was funded by an AusAID Australian Development Research Award (0800028) to Méheux and Dominey-Howes. We gratefully acknowledge this funding. The views expressed in this publication are those of the authors and not necessarily those of the AusAID. We thank all participants for their help, particularly the participants from Fasito'otai village, Samoa. We thank Benjamin Davis, Chris Stokes and Lisa Staruszkiewicz at AusAID for their help and guidance throughout. This work was conducted according to Human Ethics standards at UNSW approval 08/2009/20.

Edited by: N. R. Dalezios

Reviewed by: N. Pavol and another anonymous referee

\section{References}

Allen, K. M.: Community-based disaster preparedness and climate adaptation: local capacity building in the Philippines, Disasters, 30, 81-101, 2006.

Atkinson, R. and Flint, F.: Accessing hidden and hard-to-reach populations: Snowball research strategies, in: Social Research UPDATE, editd by: Gilbert, N., Department of Sociology, University of Surrey, UK, 2001.

AusAID: Investing in a Safer Future A Disaster Risk Reduction policy for the Australian aid program, AusAID, Canberra, 42, 2009.

Ayers, J. and Huq, S.: Community based adaptation to climate change: an update, IIED, London, UK, 2009.

Bazeley, P.: Qualitiative data analysis with NVivo, Sage Publications, 2007.

Bettencourt, S., Croad, R., Freeman, P., Hay, J., Jones, R., King, P., Lal, P., Mearns, A., Miller, G., Pswarayi-Riddihough, I., Simp- son, A., Teuatabo, N., Trotz, U., and Van Aalst, M.: Not if but when: Adapting to natural hazards in the Pacific Islands Region, 2006.

Biermann, F., Pattberg, P., van Asselt, H., and Zelli, F.: Fragmentation of Global Governance Architectures: The case of climate policy, Vrije Universiteit Amsterdam Institute for Environmental Studies (IVM), Amsterdam, 2007.

CARE-Bangladesh: How can we drink saline water? Advocacy Campaign of the "Pani Committee" (Water Committee), 2005.

Caritas Australia: Building disaster response and preparedness of Caritas partners in the Pacific, Australia, 2008.

Daly, M., Poutasi, N., Nelson, F., and Kohlhase, J.: Reducing the climate vulnerability of coastal communities in Samoa, J. Int. Dev., 22, 265-281, 2010.

Delica-Willison, Z. and Willison, R.: Vulnerability Reduction: A Task for the Vulnerable People Themselves, in: Mapping Vulnerability: Disasters, Development and People, edited by: Bankoff, G., Frerks, G., and Hilhorst, D., Earthscan, London, 145-158, 2004.

Food and Agriculture Organization: Climate change and food security in Pacific Island Countries, FAO, Rome, 281 pp., 2008.

Gero, A., Meheux, K., and Dominey-Howes, D.: Disaster risk reduction and climate change adaptation in the Pacific: The challenge of integration, University of New South Wales, Sydney, 2010.

Glantz, M.: Climate Affairs: A Primer, Island Press, Washington DC, 2003.

Global Environment Facility: Financing Adaptation Action, 36, 2009.

Helmer, M. and Hilhorst, D.: Natural disasters and climate change, Disasters, 30, 1-4, 2006.

IFRC: What is VCA, International Federation of Red Cross and Red Crescent Societies, Geneva, 51 pp., 2006.

International Strategy for Disaster Reduction: Hyogo Framework for Action 2005-2015: Building the Resilience of Nations and Communities to Disasters, World Conference on Disaster Reduction, Kobe, Hyogo, Japan, 2005,

IPCC: Climate Change 2007: 4th Assessment Report, IPCC, 2007.

Jennings, G. R.: Interviewing: A focus on qualitative techniques, in: Tourism research methods: Integrating theory with practice, edited by: Ritchie, B. W., Burns, P., and Palmer, C., CABI Publishing, 2005.

Kaly, U., Pratt, C., and Howorth, R.: Towards managing environmental vulnerability in Small Island Developing States (SIDS), Suva Fiji, 2002.

Kelman, I., Mercer, J., and West, J.: Combining different knowledges: community-based climate change adaptation in small island developing states, Participatory Learning and Action, 60, 41-53, 2009.

Lal, P. N., Rita, R., and Khatri, N.: Economic Costs of the 2009 Floods in the Fiji Sugar Belt and Policy Implications, IUCN, Gland, Switzerland, xi+52, 2009.

Lane, R. and McNaught, R.: Building gendered approaches to adaptation in the Pacific, Gender and Development, 17, 67-80, 2009.

Lewis, J.: Climate and disaster reduction, Tiempo Climate Newswatch, International Institute for Environment and Development (IIED), available at: http://www.tiempocyberclimate. org/newswatch/comment070217.htm, 2007.

Mataki, M., Koshy, K., and Nair, V.: Implementing Climate Change 
Adaptation in the Pacific Islands: Adapting to Present Climate Variability and Extreme Weather Events in Navua (Fiji), Assessments of Impacts and Adaptations to Climate Change (AIACC), Florida, USA, 2006.

Meheux, K., Dominey-Howes, D., and Lloyd, K.: Natural Hazard Impacts in small island developing states: A review of current knowledge and future research needs, Nat. Hazards, 40, 429446, 2007.

Mercer, J.: Disaster Risk Reduction or Climate Change Adaptation: Are we reinventing the wheel?, J. Int. Dev., 22, 247-264, 2010.

Mercer, J., Kelman, I., Suchet-Pearson, S., and Lloyd, K.: Integrating indigenous and scientific knowledge bases for disaster risk reduction in Papua New Guinea, Geogr. Ann. B, 91, 157-183, 2009.

Mimura, N., Nurse, L., McLean, R., Agard, J., Brigulio, L., Lefale, P., Payet, R., and Sem, G.: Small islands, in: Climate Change 2007: Impacts, Adaptation and Vulnerability. Contribution of Working Group II to the Fourth Assessment Report of the Intergovernmental Panel on Climate Change, edited by: Parry, M. L., Canziani, O. F., Palutikof, J. P., van der Linden, P. J., Hanson, C. E., Cambridge University Press, Cambridge, 687-716, 2007.

Ministry of Natural Resources and Environment (MNRE): National Adaptation Programme of Action, MNRE, Apia, Samoa, 66 pp., 2005.

Mitchell, T. and van Aalst, M.K.: Convergence of Disaster Risk Reduction and Climate Change Adaptation, A Review for DFID, $1-22,2008$

Nicholls, N.: CDB Disaster Management Programme: Lessons of experience, Caribbean Disaster Preparedness Seminar, Montego Bay, Jamaica, 9-10 January 2001, 2001.

Nunn, P.: Responding to the Challenges of Climate Change in the Pacific Islands: Management and Technological Imperatives, Clim. Res., 10, 211-231, 2009.

O'Brien, G., O'Keefe, P., Rose, J., and Wisner, B.: Climate change and disaster management, Disasters, 30, 64-80, 2006.

OCHA: Samoa/Tonga Tsunami Situation Report 6, OCHA, Suva, 6 pp., 2009.

Pelling, M. and Uitto, J. I.: Small Island developing states: natural disaster vulnerability and global change, Environmental Hazards, 3, 49-62, 2001.
Punch, K.: Introduction to Social Research: Quantitative and Qualitative Approaches, Sage Publications, London, 2005.

Red Cross: Climate Guide, Red Cross/Red Crescent Climate Centre, The Hague, 73 pp., 2007.

SOPAC: Building the resilience of nations and communities to disasters: A framework for action 2005-2015, Suva, 2005.

Thomalla, F., Downing, T., Spanger-Siegfried, E., Han, G., and Rockstrom, J.: Reducing Hazard Vulnerability: towards a common approach between disaster risk reduction and climate adaptation, Disasters, 30, 39-48, 2006

Uitto, J. I. and Shaw, R.: Adaptation to climate change: Promoting Community-based approaches in the developing countries, Sansai, 1, 93-108, 2006.

United Nations Development Programme: Local Level Risk Management Draft, UNDP Bureau of Crisis Prevention and Recovery, 21 pp., 2006.

United Nations Development Programme: An integrated Local Level Risk Management Approach to Reducing Flooding Risk in the Navua Region, Fiji, UNDP, Suva, Fiji, 2007.

United Nations Development Programme (UNDP): UNDP Project Document: Community Based Adaptation, UNDP, 2008.

United Nations International Strategy for Disaster Reduction (UNISDR): Terminology: Basic Terms of Disaster Risk Reduction, UNISDR, Geneva, 2004.

van Aalst, M. K.: Comminucating Changing Risks, Forced Migration Review, 31, 57-58, 2008.

van Aalst, M. K., Cannon, T., and Burton, I.: Community level adaptation to climate change: the potential role of participatory community risk assessment, Global Environ. Change, 18, 165179, 2008.

Venton, P. and La Trobe, S.: Linking climate change adaptation and disaster risk reduction, Tearfund, United Kingdom, 19 pp., 2008.

Warner, J.: Risk Regime Change and Political Entrepreneurship: River Management in the Netherlands and Bangladesh, in: Natural Disasters and Development in a Globalizing World, edited by: Pelling, M., Routledge, London, UK, 185-198, 2003. 